\title{
The Failure Factors of Collective Action in Promoting the Recognition of Customary Forest: Case of Kenegerian Rumbio Customary Forest in Riau Province
}

\author{
Fahrul Rozi Sembiring ${ }^{1}$, Leti Sundawati ${ }^{2 *}$, Bramasto Nugroho ${ }^{2}$

\begin{abstract}
${ }^{1}$ Graduate Program of Forest Management, Faculty of Forestry, IPB University, Academic Ring Road Campus IPB Dramaga, Bogor, Indonesia 16680 Dramaga, Bogor, Indonesia 16680
\end{abstract} \\ ${ }^{2}$ Department of Forest Management, Faculty of Forestry and Environment, IPB University, Academic Ring Road Campus IPB
}

Received August 21, 2020/Accepted July 2, 2021

\begin{abstract}
One of the five schemes in social forestry program in Indonesia is customary forest recognition. Kenegerian Rumbio Customary Forest, a customary forest in Riau Province, is failed in the recognition process. The objectives of this study are to analyze the failure factors of collective action and to formulate strategies to encourage the success of collective action on recognition of Kenegerian Rumbio Customary Forest. This research was built by using both quantitative and qualitative approach where the data were collected by using survey and in-depth interviews. The research results found that improper facilitation caused by communication issues between involved parties, the absence of the symbolic power, the failure in forming the common knowledge are the factors leading to the failure of collective action. To reconstruct the collective action, this study offered four strategies: (1) to frequently communicate with personal approach to the two highest indigenous leaders with whom facilitators have difficulty communicating well, (2) to mediate the two conflicted indigenous leaders for generating their motivation to propose their forest, (3) to conduct socialization to all indigenous leaders (40 jini) and community representatives to increase an understanding regarding the purpose and importance of recognition of customary forest, and (4) to conduct a participatory mapping to reduce area border issues among two sub-tribes.
\end{abstract}

Keywords: common knowledge, symbolic power, strategy, social capital, social forestry.

*Correspondence author, email:lsundawati@gmail.com

\section{Introduction}

Customary forests and its people are an inseparable unit. The interaction between the two is typically characterized by the management of customary forests using a local wisdom. The existence of local wisdom in the forest management by indigenous people reflecting a close relationship of people and forest. Therefore, sustaining the existence of customary forests. Forest is an essential natural resource, acting as a source of livelihoods such as food suppliers, economy, medicine, residential areas, sources of inspiration for works of art (paintings, sculptures, dances) and religion (Nurrochmat et al., 2012; Nugroho et al., 2018). For indigenous people, forest is not just a source of livelihoods, but also playing an important role on their life.

Before 2013, indigenous peoples' rights on forest were unclear. This was reflected in the Forestry Law Number $41 / 1999$, which stated that customary forests are state-owned forests within the territories of indigenous and tribal peoples. The long-time neglect of indigenous peoples' rights on forest ownership by government encouraged the emergence of indigenous people alliances supported by non-government organizations to propose the right of indigenous people on managing own forests through a judicial review on Indonesia's Forestry Law. The issuance of the Decision of the Constitutional Court Number 35/PUU-X/2012 approves that customary forests are forest located within the territories of the indigenous people and it is not part of the state forest areas. In its decision, Constitutional Court fulfilled the word of "state" in article 1 paragraph 6 to be written off. It does not has no binding legal force anymore. So the article 1 paragraph 6 in Forestry Law Number 14/1999 changed to be "customary forests are forests within the territories of indigenous and tribal peoples". However, not all forests managed by indigenous people are automatically recognized as customary forests. The existence of indigenous people has to be verified before the government recognizes the status of the customary forests. In early years, the process of customary forests recognition was heavily bureaucratic, especially areas located within state forest. Therefore, only a few customary forests were successfully recognized by the government.

The 2016's recognition scheme of customary forests in social forestry program launched by the Ministry of Environment and Forestry has accelerated the process of customary forests recognition. In its scheme, the local and central governments facilitate indigenous people for proposing their forest to be recognized as customary forest. The process of recognizing indigenous people's rights to manage their forest requires a joint action between the indigenous people and other stakeholders, which is also 
referred to as collective action. Collective action is a voluntary action taken by more than one individual or group who contribute to an effort in achieving a goal (Ostrom, 1990; Ostrom, 2004; Rokhani et al., 2016).

The indigenous people of Kenegerian Rumbio in Kampar Regency, Riau Province, has been managing their forest using traditional value practices for generations (Rijal \& Noer, 2013). In 2018 and 2019, the indigenous people of Kenegerian Rumbio have tried to obtain the recognition of their customary forest. With the help of other entities, i.e. NGOs and the Environment Agency of Kampar Regency, they formed a collective action. However, the collective action to promote the recognition of Kenegerian Rumbio customary forest was not yet succeeded in achieving their desired goals. Why the collective action to propose the recognition of Kenegerian Rumbio customary forest was unsuccessful? What were the causing factors?

Collective action can be understood by looking at the social capital concept. Ostrom and Ahn (2009) and Asmin (2018) stated that social capital is a condition for the formation of collective action and useful for understanding, describing, and influencing collective action by the community. Suharti et al. (2016) said that the stronger the social capital, the easier the agreement for the realization of collective action is (Suharti et al., 2016). By knowing its social capital, it will explain community capacity (Suharjito, 2013). Furthermore, Beard \& Dasgupta (2006) stated that community capacity is fundamental to carry out collective action in achieving community-based development.

Some scientists stated that social capital is not enough to encourage the formation of collective action. In addition to social capital, there are other factors that contribute to the creation of collective action. Bourdieu (1989), Ishihara and Pascual (2009), and Suharti et al. (2016) stated that common knowledge and symbolic power are concepts that promote the formation of collective action in a community besides social capital. Suharti et al. (2016) explained that regions which have the same typology of social capital and faced the same problems do not necessarily produce the same attitudes and reactions due to the presence of figures who become role models (symbolic power) in each region. Furthermore, Ishihara \& Pascual (2009) explained that the strong social capital of a group of people does not always lead to the formation of collective action. The first focus that needs to be done is the ability to form common knowledge. The creation of common knowledge is related to the capacity to represent individual preferences as if they were the community's preferences through symbolic power. Ostrom (2010) stated that the success or failure of a collective action concerned with the so called "the core relationships", i.e. a participant's trust in other participants in collective action, the participant's reputation, and the likelihood of using the norm of reciprocity.

Has the collective action undertaken by indigenous peoples of Kenegerian Rumbio fulfilled the elements for forming collective action (social capital, symbolic power, common knowledge)? The objectives of this study are to analyze the failure of collective action of Kenegerian Rumbio indigenous peoples by identifying the elements of collective action (social capital, symbolic power, and common knowledge) and formulating strategies to encourage the success of collective action on recognition of Kenegerian Rumbio customary forest.

\section{Methods}

The study was conducted for three months (December 2019-February 2020) in the Kenegerian Rumbio indigenous area, specifically four villages surrounding the customary forest, namely Rumbio, Pulau Sarak, Padang Mutung, and Koto Tibun in Kampar Regency, Riau Province (Figure 1). This research used qualitative and quantitative approach where the data were collected by using the survey method and in-depth interview.

For the community respondents, they were selected using the purposive sampling method based on the number of household heads in each village using the Slovin method with a fault tolerance limit of $10 \%$ (Umar, 2005). The criteria of the respondents was the community living around the customary forest which was administratively divided into four villages. The number of respondents selected proportionally was 97 people, divided into 28 people in Rumbio Village, 38 people in Padang Mutung Village, 17 people in Koto Tibun Village, and 14 people in Pulau Sarak Village. To obtain in-depth information about institutional and cultural community, social capital, interest and influence of stakeholders, common knowledge and symbolic power, 18 people were selected as key informants by snowball sampling method.

Analyzing the elements of social capital level in the community was done in a qualitative descriptive manner where the elements of social capital used were trust, social norms, and social networks (Putnam, 1993). The results of the ranking used a Likert scale on the elements of social capital and then analyzed using the Kruskal Wallis test to see the differences in the three components of social capital in each village, in which if they showed the differences, then they were further tested using the Dunn's Test.

Stakeholder support was mapped using the categorization of stakeholders by Reed et al. (2009). It used to observe the level of interest and influence of stakeholders. The support of the parties, symbolic power, and common knowledge were analyzed descriptively and qualitatively. Strategy formulation in this study was a synthesis of the analysis on physical condition of the region, social capital, symbolic power, and common knowledge associated with the theory of core relationship proposed by Ostrom (2010). Ostrom (2010) stated that the success of a collective action related to the core relationships, i.e. trust between the participants who are involved into the collective action, the reputation of participants, and the norms of reciprocity.

\section{Results and Discussion}

The condition of Kenegerian Rumbio Geographically, Kenegerian Rumbio customary forest is located at N0 $0^{\circ} 18^{\prime} 50.0^{\prime \prime}-00^{\circ} 19^{\prime} 05.0^{\prime \prime}$ and E101'07'30.0"$101^{\circ} 08^{\prime} 00.0^{\prime \prime}$. To go there, it takes \pm 45 minutes driving from Pekanbaru (the capital of Riau Province) with a distance of \pm $40 \mathrm{~km}$. While from Bangkinang (capital of Kampar regency), it could be reached within \pm 15 minutes. 


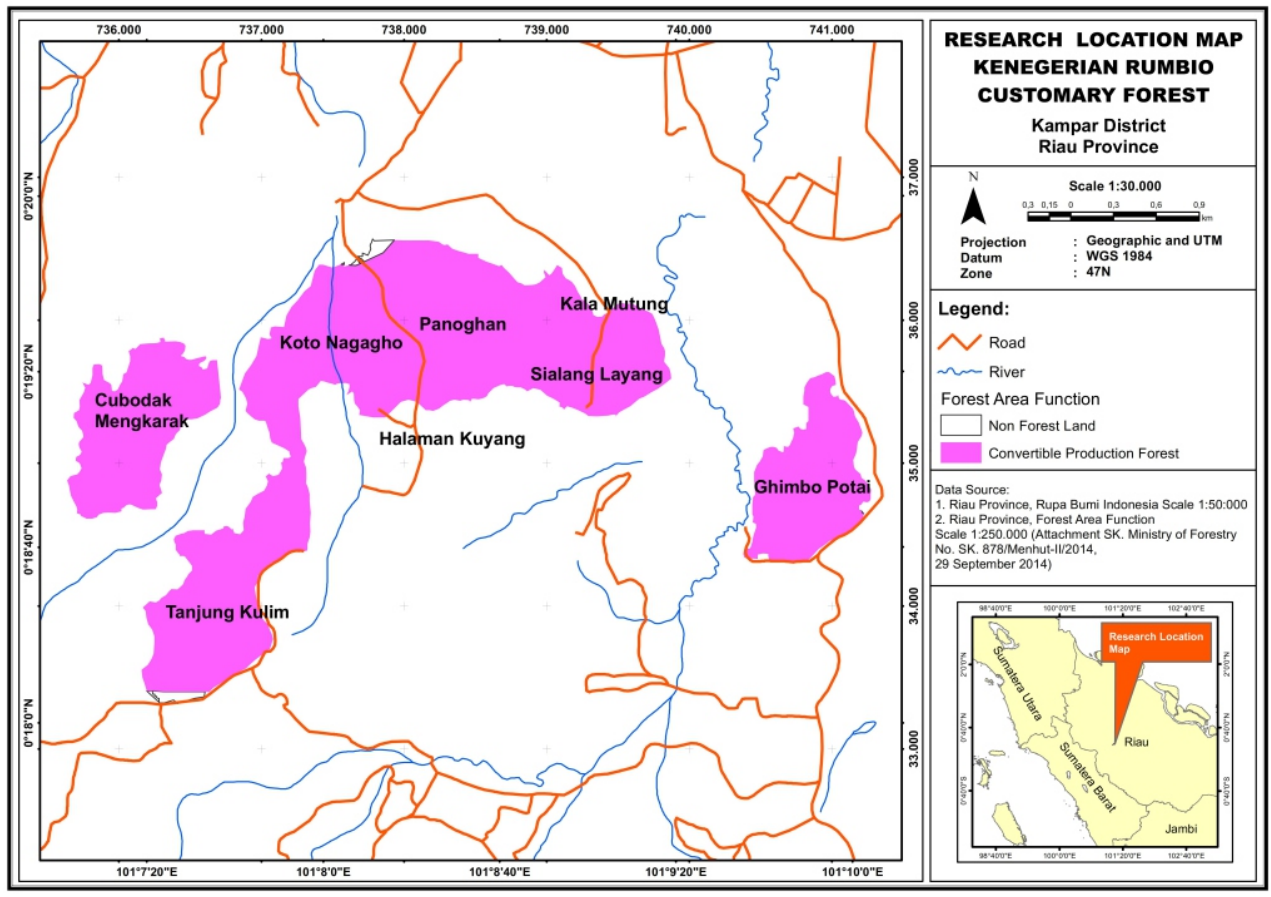

Figure 1 Map of research location.

The origin of Kenegerian Rumbio comes from two datuok who lived in Koto Tibun and Koto Tinggi areas around the fifth and sixth centuries since the Srivijaya era. Datuok Andiko is a datuok from Domo Tribe who lives in Koto Tibun and Datuok Nan Sakti is a datuok from Putopang Tribe who lives in Koto Tinggi (BRWA 2020). The two datuok have always worked together in building Kenegerian Rumbio. That what makes the generation of their tribes have always been crowned as the highest customary leaders in Kenegerian Rumbio.

The community of Kenegerian Rumbio consists of five sub-tribes namely Putopang, Domo, Kampai, Chaniago, and Piliang, which adhere to a matrilineal system. Each subtribes has one highest tribe leader who is assisted by one other leader. This means the highest tribe leaders consist of ten people. These ten people have three employees namely dubalang, malin, and monti. Dubalang is an employee in the field of security, malin is in the field of religion, while monti is in the field of administration or negotiation. So, the overall datuok are forty that also known as 40 jini.

In the Kenegerian Rumbio current structure, Datuok Ulak Simano and Datuok Godang are the highest customary leaders. Datuok Ulak Simano and Datuok Godang have the same level of leadership in Kenegerian Rumbio. Datuok Godang takes care of external affairs while Datuok Ulak Simano takes care of internal affairs. Datuok Godang becomes the representative of Kenegerian Rumbio if there is an invitation from the outside, for example, from the regency government or dunsanak. Both Datuok communicate continuously and help each other in resolving their state affairs.

The customary forest belong to two sub-tribes: Putopang and Domo tribes. The forest has a 499.3 ha area. This number is smaller than what Rijal \& Noer (2013) reported, which is
538 ha. The forest status is in the convertible production forest (CPF), located mostly at $>100 \mathrm{~m}$ above sea level with dominant slope is in the flat class. Bappeda Kampar \& P4WIPB (2015) stated that the soil type contained in the customary forest consists of alluvial, latosol, and podsolic types. While the rainfall is classified very low with a value of $1.28 \mathrm{~mm} \mathrm{day}^{-1}$ of rain.

Kenegerian Rumbio customary forest is divided into several naming areas based on the characteristics of the areas, namely Cubodak Mengkarak, Panoghan, Sialang Layang, Kala Mutung, Halaman Kuyang, Imbo Potai, Koto Nagagho, and Tanjung Kulim. It still has the potential plant of typical lowland forest such as medicinal plants, fruits, and other wood plants (Zulfahmi et al., 2015; Hasibuan et al., 2016; Afif et al., 2016; Hasugian et al., 2017; Sribudiani et al., 2019). The types of animals in the forest are quite diverse such as thorny turtles, wild boar, squirrels, bears, monkeys, monitor lizards, crooked, hornbills, deer, porcupines, monkeys, king prawns, deer, hoops, birds, pangolin, squirrels, and ungko (Bappeda Kampar \& P4W-IPB, 2015).

The most well-known potential use of environmental services from the forest is its freshwater that could be used every day by the community. Several studies have been carried out on the potential of freshwater economically and institutionally (Arfitriyana et al., 2015; Insusanty \& Ratnaningsih, 2015; Hidayat et al., 2015). In addition to the potential of water, other environmental services often used in the seasonal condition is the tourism with the beauty of the forest landscape. The attractions that can be valuable to visitors are forests with fresh air, large-diameter trees, unique biodiversity such as nephentes, and others (Alviya et al., 2018). However, this tourism potential is not supported by the maintenance of infrastructure, which is currently beginning to fail. 
Kenegerian Rumbio's community social capital In this study, the observed social capital consisted of trust, norms, and networks as been put forward by Putnam (1993) as follows:

Trust Kenegerian Rumbio indigenous people consisted of five tribes: Putopang, Domo, Kampai, Piliang, and Chaniago. These five tribes follow a matrilineal system, which means that their mother's tribe will descend to their children's tribe. Each tribe has one tribal headman who is assisted by another headman. Each tribal headman, also oftenly called ninik mamak or datuok, is assisted by three employees, namely Dubalang, Malin, and Monti. They work in security, religion, administration, or negotiation, respectively. In total, there are 40 datuok or ninik mamak, which is called 40 jini. Among these 40 jini, there are two people chosen as the highest indigenous leaders or datuok pucuk. Both of them have the title consist of Pucuk adat kenegerian and Pucuk kerapatan adat kenegerian, which have the same level in leading Kenegerian Rumbio. Pucuk adat kenegerian manages internal affairs while Pucuk kerapatan adat kenegerian takes care external affairs. Managing internal affairs means solving problems or affairs within the state while taking care external affairs means being a delegation if there is an invitation from the outsiders, for example, from the regency or dunsanak. Both leaders communicate and helpeach other in resolving affairs.

Community trust in the four villages has a high trust category, with a total score of 22.37 (Table 1). The highest is trust in religious leaders. It is very reasonable because most of the people of Kenegerian Rumbio are muslim and upheld religious values in their customs as the indigenous adage states "adat basandi syarak, syarak basandi kitabullah".

As a community that is highly upholding the tribes, they have a powerful bond to their fellow people who have the same ethnic group. They would be willing to help people from the same tribe who hit by disaster, providing loans, and leaving their house to the fellow tribe if traveling. The score of community trust towards people of the same ethnic group is higher compared to those of different ethnic groups, respectively, 2.94 and 2.78. However, the two indicators are still classified in the high category. Ethnic differences do not prevent people from interacting with each other and did not cause friction between people. Furthermore, the community is so friendly to others from outside the area who come to their homes.

The results of the trust analysis in each village showed that the people still has relatively high trust among members of the community (Table 2). Hasbullah (2006) stated that collective action carried out based on high mutual trust in the community will increase community participation, especially in constructive situations for mutual progress. Moreover, a high level of mutual trust in the community will also lead to an attitude of complying with applicable values and norms. The quantitative analysis, which was conducted using Kruskal-Wallis non-parametric analysis with a confidence level of $95 \%$, showed a significant result, $p$-value $=.02$. Therefore, further tests were conducted using Dunn's test to find out which villages had differences.

Dunn's test results showed that the trust of Koto Tibun people is significantly different from the trust of Rumbio and Pulau Sarak people. Koto Tibun Village became a definitive village in 2011 as a result of the division of Padang Mutung Village. According to Hasbullah (2006), the significant differences of community trust will significantly affect the attitude and reaction of the spirit of community collectivity. Therefore, community participation will be different for collective action in these villages.

The norms Kenegerian Rumbio has indigenous rules that has existed for generations. It is based on religious rules with the term adat basandi syarak, syarak basandi kitabullah (indigenous rules based on religious rules, religious rules based on Al-Quran and hadith). It is also applied to preserve the forest for the benefit of the people consisting of allowed and not allowed activities (Table 3 ).

Table 1 Community trust level around customary forest

\begin{tabular}{lcc}
\hline \multicolumn{1}{c}{ Indicator } & Average & Category \\
\hline Trust other parties to be able to preserve the forest & 2.82 & High \\
Trust in collaboration with fellow communities & 2.81 & High \\
Trust built with people of the same ethnic group & 2.94 & High \\
Trust built with people of different ethnic & 2.78 & High \\
Trust in government officials & 2.64 & High \\
Trust in community leaders or customs & 2.92 & High \\
Trust in religious leaders & 2.96 & High \\
Trust in other parties (NGOs/Private) & 2.49 & Moderate \\
\hline Total & 22.37 & High \\
\hline
\end{tabular}

Table 2 Community trust per village around the customary forest

\begin{tabular}{lcc}
\hline \multicolumn{1}{c}{ Villages } & Total score & Category \\
\hline Rumbio & $23.18^{\mathrm{b}}$ & High \\
Padang Mutung & $22.23^{\mathrm{ab}}$ & High \\
Pulau Sarak & $22.96^{\mathrm{b}}$ & High \\
Koto Tibun & $20.97^{\mathrm{a}}$ & High \\
\hline
\end{tabular}

Information: Groups sharing a letter are not significantly different, $=0.05$, according to Dunn's Test 
The community are accustomed to living within indigenous norms which are relatively strong and rooted in daily life. In addition to indigenous norms, they also follow applicable legal norms as a community living within a country, especially those relating to the forest. In that case, there is a warning board forbidding forest destruction. Social sanctions will be given if violating the norms. For instance, a fine would be applied to the rules violation, marriage to the fellow tribe would be ostracized, and others.

Overall, the community norms found in the four villages are still relatively high, with a score of 25.86 (Table 4). The people in these four villages still uphold the importance of honesty, politeness, and harmony in daily relationships. These can be seen in the three indicators having a score of 3.00 each. The community also still reveals an excellent tendency in understanding and adherence to indigenous norms, religious norms, government regulations.

The results of the analysis of community norms per village showed that the community in each village still operate the applied norms because it was classified in the high category (Table 5). Kruskal Wallis analysis of four villages showed insignificant results, $p$-value $=.47$. It revealed that the norms understood and obeyed by the people in the four villages did not have differences or were relatively the same. Saputro (2012) stated that the social life of society will be orderly with the application of social norms. Therefore, social norms still adhered to by the village community would benefit social life in the villages in Kenegerian Rumbio.

Social network Overall, the level of community social networks in four villages was relatively low (Table 6). It was suspected because the community spent more of its day-today living with various professions. The average family member joining the organization consisted of only 1-2 people, namely father and mother. Usually, they became

Table 3 Indigenous rules in preserving the forest

\begin{tabular}{l} 
Indigenous rules \\
\hline Can not cut down trees* \\
Can not harvest the fruits using ape or monkey \\
Can not take honey without the permission of ninik mamak \\
Can not hunt wild animals \\
Can not take excessive amount of medicinal plants \\
Can not change the function and position of forest $*$ \\
Can not fire the forest \\
Can not be arrogant in customary forest \\
Can not commit immortality and speak dirty words in the forest \\
Can not enter the customary forest without the permission of ninik mamak \\
Can take firewood from the fallen branches \\
Can do research for the development of science * \\
Source: *Indigenous constitution of Kenegerian Rumbio Number 1 in 2007
\end{tabular}

Table 4 Community norms around customary forest

\begin{tabular}{lcc}
\hline \multicolumn{1}{c}{ Indicator } & Average & Category \\
\hline $\begin{array}{l}\text { The understanding of the existence of unwritten rules } \\
\text { (norms/costums) binding the individual/community }\end{array}$ & 2.92 & High \\
$\begin{array}{l}\text { The obedience of the existence of unwritten rules (norms/costums) } \\
\text { binding the individual/community }\end{array}$ & 2.71 & High \\
The understanding of government rules related to customary forest & 2.86 & High \\
The obedience of government rules related to customary forest & 2.42 & Moderate \\
The understanding of religion rules & 2.98 & High \\
The obedience of religion rules & 2.97 & High \\
The understanding of the importance of honesty in society & 3.00 & High \\
The understanding of the importance of courtesy in society & 3.00 & High \\
The understanding of the importance of concord in daily life & 3.00 & High \\
\hline Total & 25.86 & High \\
\hline
\end{tabular}

Information: Low $=\leq 15 ;$ Moderate $=>15$ and $\leq 21 ;$ High $=>21$

Table 5 Community norms per village around customary forest

\begin{tabular}{lcc}
\hline \multicolumn{1}{c}{ Villages } & Total score & Category \\
\hline Rumbio & 26.29 & High \\
Padang Mutung & 25.71 & High \\
Pulau Sarak & 25.71 & High \\
Koto Tibun & 25.59 & High \\
\hline
\end{tabular}


member of religious study groups, ethnic groups, farmer groups, and social gatherings. The highest indicator score was on the willingness to build network/voluntary relationships with other parties, which was 2.37 in the medium category. It indicated that the community has the potential to support the process of recognizing customary forest, in which the process required the understanding of local people in the customary forest area.

The level of the social network in each village was also classified as low (Table 7). Kruskal Wallis analysis of community social network showed insignificant results, $p$ value $=.43$. It demonstrated that the social network of the communities in each village was relatively the same or had no difference.

Level of community social capital The level of social capital in the four villages in Kenegerian Rumbio was classified into the high category (Table 8). Based on the trust, norms, and social network of Kenegerian Rumbio indigenous people, the typology of social capital still had the characteristics of bonding type social capital. That is because the community is still alive by trying to maintain applied indigenous values and norms in social life, tend to be homogeneous with the muslim majority, still have a custom structure or hierarchy, and low social network. Even so, the indigenous people of Kenegerian Rumbio has an adaptive capacity for the development of information technology and information disclosure from the outside.

High social capital could be a potential in encouraging the process of recognizing customary forests. However, this potential might not be used to develop collective action in encouraging the process because datuok or ninik mamak, especially the two highest indigenous leaders, are the figures who have a vital and immensely influential role in the management of Kenegerian Rumbio Customary forest. They have gained legitimacy by the community as a decisionmaker in activities regarding the customary forest. The community or specifically the nephew would not take action or carry out any activities if it was not in accordance with the rules set by ninik mamak. The community highly respected every decision taken by ninik mamak. The continuous existence of the Kenegerian Rumbio customary forest to date is evidence that the community still adheres to indigenous rules set by ninik mamak. Concerning the recognition of customary forest, ninik mamak's preferences to participate or not is very necessary. Thus, high social capital will be useful in assisting the process of recognizing customary forest.

Stakeholders support The existed policy regulating the customary forest recognition is the basis for the parties to provide their support in strengthening the rights of indigenous peoples to the customary forest in Kampar Regency. In 2018, The Kampar Regency Government formed a registration team for determining indigenous law community, indigenous territory, and customary forest consisting of NGOs, government agencies, and academics with Kampar Regent Decree Number 660/DLH-IV.2/32. It is the result of hearings conducted by NGOs to The Kampar

Table 6 Community's social network of the villages around customary forest

\begin{tabular}{lcc}
\multicolumn{1}{c}{ Indicator } & Average & Category \\
\hline The number of family members following organization & 1.51 & Moderate \\
The number of organizations followed & 1.65 & Moderate \\
The participation level of community in group events or & 1.07 & Low \\
customs & & \\
The willingness to build network/relationship voluntarily & 2.37 & Moderate \\
Cooperation among communities in local area & 1.15 & Low \\
Cooperation among groups out of local area & 1.02 & Low \\
Togetherness in organization if a problem occurs & 1.43 & Low \\
\hline Total & 10.21 & Low \\
\hline
\end{tabular}

Information: Low $=\leq 11.67 ;$ Moderate $=>11.67$ and $\leq 16.33 ;$ High $=>16.33$

Table 7 Community's social networks per village around customary forests

\begin{tabular}{lcc}
\hline \multicolumn{1}{c}{ Villages } & Total score & Category \\
\hline Rumbio & 10.71 & Low \\
Padang Mutung & 9.29 & Low \\
Pulau Sarak & 11.71 & Low \\
Koto Tibun & 10.17 & Low \\
\hline
\end{tabular}

Table 8 The level of community's social capital in Kenegerian Rumbio

\begin{tabular}{lccc}
\hline The elements of social capital & Score & Average & Maximum -Minimum \\
\hline Trust & 2196 & 22.37 & $24-8$ \\
Social norms & 2508 & 25.86 & $27-9$ \\
Social networks & 990 & 10.21 & $21-7$ \\
\hline
\end{tabular}

Information: Low $=\leq 40 ;$ Moderate $=>40$ and $\leq 56 ;$ High $=>56$ 
Regency Office of the Environment (ROE). It is also a form of facilitation of ROE as a formal institution engaged in the field at the district level, which also made ROE as the leading sector. Futhermore, other reason for the inclusion of Kenegerian Rumbio in the process of recognizing their rights to customary forests is that the Kenegerian Rumbio people still meet the elements or criteria of indigenous peoples in the explanation of article 67 of Law Number 41/1999 concerning Forestry.

Moreover, there are two understandings expressed by the datuok about the importance of the Kenegerian Rumbio customary forest to be recognized in the social forestry scheme, namely: 1) The Kenegerian Rumbio customary forest has been preserved for generations, ancestral heritage, safekeeping to their grandchildren, so there is a sense of willingness to protect the forest; 2) It does not rule out the possibility that there were people who try to damage it. In addition, the security of forest conducted was not optimal because of the very large customary forest and the lack of security personnel, so the possibility of destruction could occur at any time.

This awareness is the first step for ninik mamak to open opportunities for collective action in encouraging the recognition of Kenegerian Rumbio customary forest with other parties. In addition, the lack of understanding of ninik mamak regarding the process of recognizing customary forest made it necessary to be facilitated by outside parties. Therefore, ninik mamak as a figure having the legitimacy of indigenous people can work together with outsiders to improve their rights. The stakeholders identified as participants in the process of recognizing Kenegerian Rumbio customary forest consisted of government institutions, informal institutions, academicians, and indigenous leaders (Figure 2).

Symbolic power, common knowledge, and collective action The position of the two highest indigenous leaders could actually be a symbolic power because the community legitimizes the forest issue to them. Symbolic power can make the potential of social capital as a symbolic capital by making their preference as general preference in forming common knowledge (Bourdieu, 1989; Ishihara \& Pascual, 2009). Therefore, high social capital will only be a potential resource if there is no symbolic power. So, the willingness of

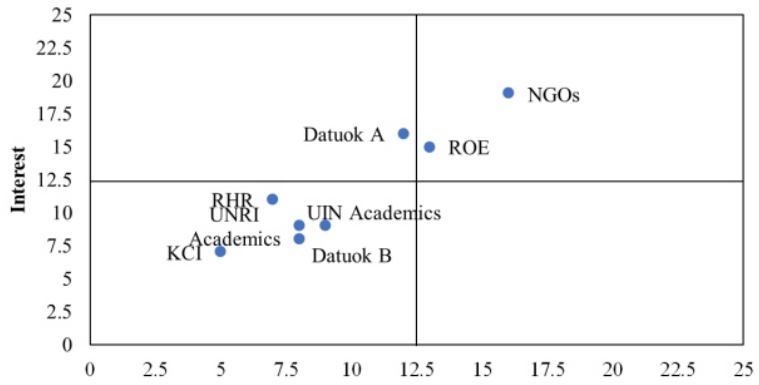

Information: Non-governmental Organizations (NGOs), Environmental Agency (EA), Regional House of Representative (RHR), Kampar Indigenous Institution (KCI), Universitas Islam Negeri (UIN), Universitas Riau(UNRI).

Figure 2 The mapping of participating stakeholders. both the highest indigenous leaders to propose was very necessary for relation to the recognition of customary forest. This thing also confirms the statement of Ishihara and Pascual (2009) that social capital alone is not enough to encourage the realization of collective action in natural resource management. Other factors that will maximize social capital to promote the achievement of collective action in a natural resources management are symbolic power and common knowledge.

Ideally, indigenous people has an active role in proposing their customary forest areas to get recognition by the government. However, in Kenegerian Rumbio, the urge to make proposals emerged from NGOs. They synergized with one another to form a work team. As usual, it needed government involvement, so the NGO working team conducted a hearing with the ROE by explaining the policies, the technical in submitting proposals to the central government, the possible involvement of the parties, and the role of the regional government. When the ROE received the presentation, they facilitated the ideas of the NGO work team and conveyed to the leaders above them until the Kampar Regent's Decree was issued on the registration team for the establishment of indigenous law communities, indigenous areas, and customary forest. The members of the team were NGOs, Kampar Regency Offices, and academics.

The decision of the two highest indigenous leaders to take part in proposing the recognition of customary forests had the consequence of preparing the required documents and initially proceeding well. The proposal process encountered obstacles when the document required the signature of the two highest leaders. One of them was not willing to sign the letter of submission because the indigenous title listed in the submission letter was not following the wish of one of the two leaders. Each the highest indigenous leaders had a different version of the story related to the traditional title. The first version said that one of the highest leaders was Pucuk Adat Kenegerian Rumbio and the other was Pucuk Kerapatan Adat Kenegerian Rumbio. While the second version said that there was only one highest indigenous leader in the area. The problem with the indigenous title of the two highest indigenous leaders was the cause of the obstruction of the customary forest proposal. The work team repeatedly held discussion and scheduled the two indigenous leaders to meet at one table but it never happened. This problem caused a lot of delays., To overcome it, one of the two leaders tried to propose their own tribal customary forest.

The submission process of one of the tribal customary forest run smoothly until the technical verification stage at the regional level. The consequence of the progress of one of the two tribes having customary forest was that there had to be clear boundaries between one another. However, it caused a new problem, namely the entry of the Sialang Layang area into the customary forest proposed by the other tribe. One of the two datuok stated that Sialang Layang belonged to his tribe, so he objected to this idea and would sue if it continued. The internal problems of the Kenegerian Rumbio would be difficult if the submission process continued. Even if it passed the regional verification, there would be verification from the central government, so that if it continued, it would raise questions. The work team also decided to postpone 
Kenegerian Rumbio case and returned the submission process to the indigenous community, considering that this internal issue was the authority of the two highest indigenous leaders. The work team only had a role of assisting the submission process, not solving complex internal problems. Every datuok or ninik mamak is independent, even fellow kenegerian people can not interfere in other's affairs unless requested.

Differences in the version of indigenous leaders' title and unclear territorial boundaries caused the two indigenous leaders did not play the role as a symbolic power. It was evidenced by the mapping of stakeholders that they acted as subjects and crowds. It was also due to the emergence of the idea of proposing the recognition of customary forest originating from NGOs and ROE. The ideal situation should be that proposals and ideas came from the community so that it would minimize internal problems because all decision making in the indigenous community was based on deliberation and consensus.

In this situation, symbolic power is really needed in forming a common knowledge (Ishihara \& Pascual 2009). Furthermore, Ishihara and Pascual (2009) stated that in the process of building common knowledge, it is not a simple process of levelling the preferences of all parties involved. Instead, there is a preference of those who have the power to make their preference as common knowledge, that is symbolic power. The emptiness of figure acting as a symbolic power caused the failure of the formation of community's common knowledge. This was even exacerbated by the boundaries problem. Therefore, although NGOs and ROE as facilitators wanted and encouraged the recognition of Kenegerian Rumbio customary forest, the absence of symbolic power resulting to there was no preference of symbolic power that could be used as community's common knowledge.

On the other hand, ROE and NGOs as facilitator had strong power in encouraging the recognition of the customary forest that was evidenced by their roles as key players in stakeholders mapping. Their strong power could help in forming common knowledge. The activities conducted to form it were socialization, coaching clinic, also visiting Jambi and West Sumatera for a comparative study. However, it was not able to form common knowledge because of the involved NGOs still difficult to make face-toface communication directly with one of the datuok pucuk. Ishihara and Pascual (2009) stated that common knowledge is not only formed, but it needs to share between the involved parties so that it can work to create collective action. Thus, direct communication that did not work well between the involved NGOs and one of the two indigenous leaders would disrupt the process of understanding transfer in forming common knowledge. In addition, the communication issue also caused the facilitators to be unable to consolidate the two highest indigenous leaders, so it affected the symbolic power's absence in creating collective action .

Communication issue affecting the common knowledge and symbolic power showed that the facilitators were not proper enough in running their facilitation at the time. The implication of this is the emergence of the issue of the highest customary titles where one of the highest customary leaders does not agree with and disputes over customary forest areas between the two sub-tribes in the process of applying for recognition of customary forest. In fact, the facilitators should be able to build good communication with all parties involved. Yatimah (2015) stated that facilitator communication skills are needed because facilitators must be able to develop the community. However, the situation when the lack of communication or dialogue between the facilitators and the targets caused the imbalanced relationship between the two (Jumrana \& Tawulo 2015). Furthermore, Jumrana and Tawulo (2015) argued that in carrying out their responsibilities, faclitiators must interact actively with the target by building face-to-face communication.

Therefore, the skill comunication of facilitators become crucial skill because facilitators have difficulty communicating face to face with one of the highest customary leaders. The forming communication between them was only through a middleman who was become one of the members of facilitators team. Whereas if there is a faceto-face meeting between all the facilitators and the highest customary leader with whom facilitators have difficulty communicating well, there will be a dialogue or feedback so that satisfaction is built between the parties. Therefore, the facilitator's services in encouraging the recognition of customary forests are less than optimal so that it has an impact on the formation of common knowledge and symbolic power and in the end they have not succeeded in achieving the expected goals.

In addition, if the facilitators had identified the customary forest area and institutional at the beginning of the submission process, then the facilitators would naturally obtain information on internal issues that should have been explored at the beginning. Therefore, the main focus of facilitators should be to overcome the issues found in identifying process. They can make it by developing a recurring personal communication approach toward the disputed parties. Because of according to Yatimah (2015), community potential and problem identification will be related to the accuracy in empowering the community.

The process of forming common knowledge and solidifying the two highest indigenous leaders required a long time, so that the activities conducted by facilitators did not necessarily encourage the recognition of the forest if there was an internal issue of indigenous institution. As the result of facilitators were not proper enough in running their facilitators, the problems which were already occurred had affected the core relationships between the involved parties, impacted to the failure of collective action conducted. Ostrom (2010) stated that the success or failure of collective action is related to the core of a relationship consisting of trust between participants, the reputation of participants, and reciprocity norms. It affects the level of cooperation that can be formed, and the mutual benefits that can be received by the involved parties. Ostrom (2010) also explained the external factors affecting the core relationships. External factors that can be found in this study are:

1) Face-to-face communication between the two datuok, if it was implemented then there could be positive effects on cooperation, namely the possibility of exchanging commitment between the two, behaving more cooperatively, sharing strategic information, developing 
trust, and creating shared norms (Kerr \& KaufmannGilliland, 1994; Balliet, 2010; Zeffane et al., 2011; Linde, 2018; Behrens \& Kret, 2019)

2) The number of parties involved would contribute to the process of proposing customary forest in Kenegerian Rumbio and the number was the same as other seven kenegerian area. Seven kenegerian areas had been successfully encouraged their recognition at the district level and the Ministry of Environment and Forestry had recognized the two of them

3) Information about the taken actions had an impact on the reputation between the two datuok and would affect the reputation of the kenegerian areas in front of the parties involved. The reputation of behaviour that has been carried out in the past by people involved as givers and recipients of trust effectively influences the level of trust (Charness et al., 2011)

4) Possibility to choose to enter or exit when the submission process is rolled out again, but if the problem is still not finished, then the suspension of the proposal would still occur. In this situation, each party is possible to use the principle of reciprocity for interactions that have been carried out Ostrom (2010) stated that all involved parties will not get any results because the decision-making period end when one party chooses not to play. That is because involved parties have a veto over the whole process in the making of collective action

External factors influencing the core relationship depend on which factors have an impact on the value of other factors (Ostrom, 2010). The communication factor (face-to-face communication) that cannot be happened between the two datuok causes the absence of symbolic power and failure in forming common knowledge. Zeffane et al. (2011) stated communication and trust have a strong relationship. Good trust will avoid misunderstanding and it is resulted from good communication among the involved parties. Ostrom (2010) stated that a decline in reputation, trust, and reciprocity norms will decrease the results of cooperation or does not even help to make it happen. In this case, if poor communication had occurred between the two datuok pucuk also between NGOs and one of the indigenous leaders, it would affect the trust between them and the collective actions undertaken to encourage recognition of customary forest. In a recurring situation, if face-to-face communication remained unfulfilled, the parties involved would look at the actions that had been taken affecting their reputation and used the norm of reciprocity to return to cooperating or not.

Strategies of collective action Strategies to promote collective action in recognition of customary forest are written based on the synthesis of the study results drawing causality between findings. From the synthesis of the study results, the root of the problems will be found according to the theories used in this research. The problems' root will be a critical point in constructing strategies of collective action to achieve the objective of collective action, to obtain recognition of customary forest from the central government based on the Decree of the Minister of Environment and Forestry for the common interest.

Collective action is created because of social capital factors and is encouraged by the presence of symbolic power and the formation of common knowledge (Ishihara \& Pascual, 2009). In addition, it is necessary to support policies, stakeholders factors, physical conditions, adequate socio-economic and cultural conditions to make collective action happen. The findings from partial research in the previous chapter are related to these factors, namely:

1) The physical condition of Kenegerian Rumbio customary forest area is still well proven by the existence of the potential of natural resources in the customary forest. The existed natural resources in this forest are lowland woods, wild animals, environment services

2) Community with a variety of professions and tribes still has strong bonding to the forest, it is evident that the community still utilize forest products for their daily lives especially water, fruits, and firewood that are carried out with the prevailing indigenous rules

3) The level of social capital of the community is classified as high and bonding type

4) The parties encourage the promotion of customary forest because of the existed policy, the indigenous community still have the criteria to be recognized legally, and datuok understood about the importance of recognition of customary forest

5) Central government policies are qualify to recognize the customary forest. Whereas the existed local government policies can not yet be used to encourage recognition of customary forest because they do not include indigenous people as subjects and indigenous territories as legal objects. However, the existence of a policy regarding indigenous land in the regency and province open opportunities for the existence of indigenous people and their customary forest

6) The absence of a figure becoming symbolic power is caused by the problem of the indigenous titles between the two highest indigenous leaders. The facilitators are not able to mediate the two highest indigenous leaders because the communication between the NGOs and one of the two highest indigenous leaders is not going well so that the absences of symbolic power is still happened. The problem is about who has the title as Pucuk Adat Kenegerian Rumbio and who has the title as Pucuk Kerapatan Adat Kenegerian Rumbio

7) In addition to the absence of figures who become symbolic power, common knowledge failed to form due to the process of transferring the understanding obstructed in forming common knowledge even though the activities has conducted to construct it. It happened because the facilitators can not communicate with one of the two highest indigenous leaders smoothly

8) The existence of a communication issue affected to common knowledge and symbolic power showed that facilitators are not proper enough in running their facilitation. It cause indigenous titles issue and the disputed indigenous area to come up

Based on the findings above, the factors 1-5 are supporting factors that able to encourage the recognition of customary forest. Meanwhile, factors 6-8 are obstacle factors. It will affect collective action because symbolic power and common knowledge factors are very important factors in realizing collective action based on Ishihara and Pascual (2009) theories. Therefore, for collective action to 
achieve the desired goals, the obstacle factors must be overcome by finding a right strategy. The developed strategy must be based on the problems' root found in the field and linked to the core relationship (Ostrom, 2010) (Figure 3).

The problems causing unsuccessful of collective action in encouraging the recognition of Kenegerian Rumbio Customary forest can be seen in diagram fishbone. The issues are dominated by the communication of facilitators that are not going smoothly to one of the highest indigenous leaders. It gives a huge effect because the facilitators are difficult to construct the common knowledge and to solidate the relation of two highest leaders in order to bring symbolic power up and influence the solidity of the involved parties. It also shows that the main problem from the communication issue is improper facilitators in running their facilitation (Table 9).

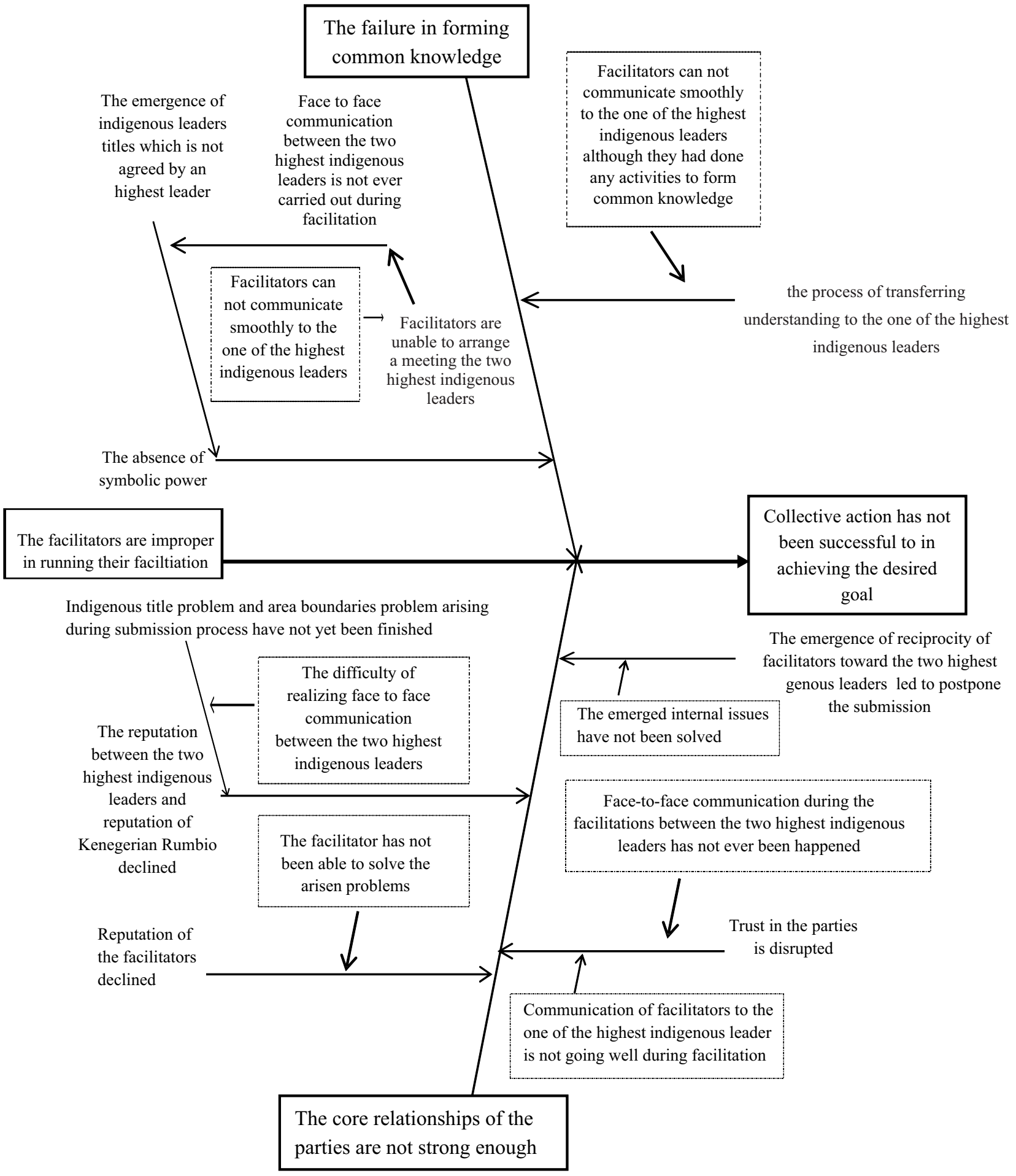

Figure 3 Fishbone diagram of problems affecting the collective action. 
Table 9 Problem causing unsuccessful of collective action

\begin{tabular}{|c|c|c|}
\hline Main problem & Effects & Causes \\
\hline $\begin{array}{l}\text { Facilitators are } \\
\text { improper in running } \\
\text { the facilitation }\end{array}$ & $\begin{array}{l}\text { The core relationships of the parties } \\
\text { are not strong enough }\end{array}$ & $\begin{array}{l}\text { - Facilitators can not communicate } \\
\text { smoothly to the one of the highest } \\
\text { indigenous leaders causing the process of } \\
\text { transferring understanding to be } \\
\text { obstructed in forming common } \\
\text { knowledge } \\
\text { - The communication issue causing the } \\
\text { absence of symbolic power still happens. } \\
\text { So it affects the failure of common } \\
\text { knowledge forming of the community } \\
\text { - The difficulty of realizing face to face } \\
\text { communication between the two highest } \\
\text { indigenous leaders causing the } \\
\text { indigenous titles and territorial forest } \\
\text { problem is still unfinished, so it affects } \\
\text { kenegerian reputation } \\
\text { - Non-smooth face to face communication } \\
\text { of the two highest indigenous leader and } \\
\text { so do NGOs to one of the leaders caused } \\
\text { the trust of involved parties to be } \\
\text { disturbed } \\
\text { - Facilitators are unable to finish the } \\
\text { appeared issues causing their reputations } \\
\text { - The reciprocity of facilitator emerges } \\
\text { toward the two highest leaders with } \\
\text { postponing the submission because of the } \\
\text { unfinished internal issues }\end{array}$ \\
\hline
\end{tabular}

Based on the main problem found, the strategies to overcome the problems are:

1) Communicating with personal approach repeatedly to the two highest indigenous leaders with whom they have difficulty communicating well. The figures who takes the personal approach is someone that can be well received by the highest customary leaders during the facilitation process. If the figures is not in the team, they need to do a reorganization of the involved facilitator members. It is intended to help the forming of common knowledge and to solidate relation of the involved parties

2) Mediating both two highest indigenous leaders together by activating the motivation of both to propose the customary forest. This strategy can be conducted to solve the problems of indigenous title and territorial forest boundaries. The ROE as a key player can be the initiator and mediator considering that this indigenous community is within its working area. In addition, if needed, the ROE can involve religious leaders in the mediation because the score of public trust in religious leader is the highest in social capital indicators

3) The facilitators can make socialization to all customary leaders (40 jini) and community representatives to improve understanding (common knowledge) related to the purpose and importance of recognizing customary forest by the government for community life. Along with socialization, the facilitators can explore historical background of the customary forests and its institutions in order to solve the problems

4) Conducting a participatory mapping to minimize the problem of borderline. This strategy will be conducted when the mediation is successful, so that the boundaries of the two sub-tribes become clear

\section{Conclusion}

The main factor causing the failure of collective action undertaken in encouraging the recognition of the Kenegerian Rumbio Customary forest is improper facilitation caused by communication issue. It leads to failure in forming common knowledge and less solidity between the involved parties. Other factor causing the failure of collective action is the absence of symbolic power. It also leads to the failure in forming common knowledge because there is no preferences used to form it by indigenous people side. The absence of symbolic power also makes the high social capital category of indigenous people has no big effect to the collective action. In order to play an optimal role, the social capital is necessary to be intervened by symbolic power (Suharti 2016). These findings confirm the criticism by Ishihara and Pascual (2009) that social capital does not always lead to the formation of collective action. According to these findings, the process of recognizing customary forest must pay attention to the internal conditions of customary institution, so that the process that has been carried out can obtain the desired results. If the internal of the indigenous institution faces a problem, it is better to resolve the problem first.

\section{Recommendation}

Therefore, the strategies to reconstruct the collective action are to communicate with personal approach repeatedly to the two highest indigenous leaders with whom facilitators have difficulty communicating well, to mediate the two conflicted highest customary leaders for generating their motivation to propose their forest, to conduct socialization to all customary leaders $(40$ jini $)$ and community representatives to increase understanding regarding the purpose and importance of recognition of 
customary forest, and to conduct a participatory mapping to reduce customary forest area border issues among two subtribes. Further research is needed on the internal conflict resolution of cutomary institution to encourage the recognition of Kenegerian Rumbio customary forest.

\section{References}

Afif, K., Yoza, D., \& Nursal. (2016). Karakteristik habitat dan penyebaran kulim (Scorodocarpus borneensis Becc.) di hutan larangan adat rumbio. Jurnal Online Mahasiswa Fakultas Pertanian Universitas Riau, 3(2).

Alviya, I., Muttaqin, M. Z., Salminah, M., \& Hamdani, F. A. U. (2018). Community-based carbon emission reduction program in protection forest. Jurnal Analisis Kebijakan Kehutanan, 15(1), 19-37. https://doi.org/10.20886/ jakk.2018.15.1.19-37

Arfitriyana, Sribudiani, E., \& Mukhamadun. (2015). Valuasi ekonomi air di hutan larangan adat Kenegerian Rumbio Desa Pulau Sarak Kecamatan Kampar Kabupaten Kampar. Jurnal Online Mahasiswa Fakultas Pertanian Universitas Riau, 2(1).

Asmin, F. (2018). Konstruksi modal sosial bagi pengelolaan hutan berbasis masyarakat: Sebuah kerangka konseptual. Jurnal Ilmu Sosial dan Humaniora, 7, 32-45. https://doi:10.23887/jish-undiksha.v7i1.13301

Bappeda Kampar \& P4W-IPB. (2015). Pemetaan batas hutan larangan adat Kenegerian Rumbio Kabupaten Kampar. Bogor: Bappeda Kampar \& P4W-IPB.

Balliet, D. (2010). Communication and cooperation in social dilemmas: A meta-analytic review. The Journal of Conflict Resolution, 54(1), 39-57.

Beard, V., \& Dasgupta, A. (2006). Collective action and community-driven development in rural and urban Indonesia. Urban Studies, 43, 1451-1468. https://doi.org/10.1080/00420980600749944

Behrens, F., \& Kret, M. E. (2019). The interplay between face-to-face contact and feedback on cooperation during real-life interactions. Journal of Nonverbal Behavior, 43(4), 513-528. https://doi.org/10.1007/s10919-01900314-1

Bourdieu P. (1989). Social space and symbolic power. Sociological Theory, 7(1), 14-25. https://doi.org/ $10.2307 / 202060$

[BRWA] Badan Registrasi Wilayah Adat. (2020, June). Wilayah adat Kenegerian Umbio. Retrieved from http://brwa.or.id/wa/view/c1NmNHB4eEIwcVk

Charness, G., Du, N., \& Yang, C-L. (2011). Trust and trustworthiness reputations in an investment game. Games and Economic Behavior, 72(2), 361-375. https://doi.org/10.1016/j.geb.2010.09.002
Hasbullah, J. (2006). Social capital (Menuju keunggulan budaya manusia Indonesia). Jakarta: MR-United Press.

Hasibuan, S., Suhesti, E., \& Insusanty, E. (2016). Kajian ekologi pasak bumi (Eurycoma longifolia Jack.) dan pemanfaatan oleh masyarakat di sekitar hutan larangan adat rumbio, Kabupaten Kampar Provinsi Riau. Wahana Forestra: Jurnal Kehutanan, 11, 34-48. https://doi.org/ 10.31849/forestra.v11i2.152

Hasugian, R. M., Yoza, D., \& Sulaeman, R. (2017). Sebaran pohon penghasil buah-buahan di hutan larangan adat Kenegerian Rumbio Kecamatan Kampar Kabupaten Kampar Provinsi Riau. Jurnal Online Mahasiswa Fakultas Pertanian Universitas Riau, 4(2).

Hidayat, T., Sadjati, E., \& Insusanty, E. (2015). Potensi dan pemanfaatan mata air sikumbang desa pulau sarak pada kawasan hutan larangan adat rumbio Kampar-Riau. Wahana Forestra: Jurnal Kehutanan, 10(1). https://doi.org/10.31849/forestra.v10i1.619

Insusanty, E., \& Ratnaningsih, A. T. (2015). Nilai manfaat ekonomi air hutan larangan adat rumbio. Wahana Forestra: Jurnal Kehutanan, 10(2). https://doi.org/ 10.31849/forestra.v10i2.228

Ishihara, H., \& Pascual, U. (2009). Social capital in community level environmental governance: A critique. Ecological Economics, 68(5), 1549-1562. https://doi.org/10.1016/j.ecolecon.2008.11.003

Jumrana., \& Tawulo, M.A. (2015). Fasilitator dalam komunikasi pemberdayaan masyarakat. Jurnal Profetik, 8(1), 19-30.

Kerr, N. L., \& Kaufman-Gilliland, C. M. (1994). Communication, commitment, and cooperation in social dilemma. Journal of Personality and Social Psychology, 66(3), 513-529. https://doi.org/10.1037/0022-3514. 66.3 .513

Linde, S. (2018). Communication and cooperation: A study of the relationship between political communication and large-scale collective action [dissertation]. Luleå: Luleå University of Technology. Retrieved from: http://diva2:1183224

Nugroho, Y. P., Pambudi, A., Harini, A., Noveri, N. P., Nurhaeni, R., Saputro, A., ..., \& Firdaus, A. (2018). Hutan adat wujud rakyat berdaulat bangsa bermartabat (Y. P. Nugroho, Ed.). Jakarta: Kementerian Lingkungan Hidup dan Kehutanan.

Nurrochmat, D. R., Hasan, F. M., Suharjito, D., Budiaman, A., Hadianto, A., Ekayati, M., ..., \& Ryandi, E. D. (2012). Ekonomi politik kehutanan: Mengurai mitos dan fakta pengelolaan hutan (D. R. Nurrochmat, \& M. F. Hasan, Eds.). Jakarta: INDEF.

Ostrom, E. (1990). Governing the commons: The evolution of 
institutions for collective action. New York: Cambridge University Press.

Ostrom, E. (2004). Understanding collective action. In R. S. Meinzen-Dick, M. Di Gregorio (Eds.), Collective action and property rights for sustainable development 2020 vision focus 11. Washington DC: International Food Policy Research Institute (IFPRI).

Ostrom, E. (2010). Analyzing collective action. Agricultural Economics, 41, 15166. https://doi.org/10.1111/j.15740862.2010.00497.x

Ostrom, E., \& Ahn, T. K. (2009). The meaning of social capital and its link to collective action (G. T. Svendsen \& G. L. H. Svendsen, Eds.). Northampton: Edward Elgar Publisher.

Putnam, R. (1993). Making democracy work: Civic traditions in modern Italy. New Jersey: Princeton University Press. https://doi.org/10.2307/j.ctt7s8r7

Reed, S., Graves, A., Dandy, N., Posthumus, H., Huback, K., Morris, J., \& Stringer, L. (2009). Who's in and why? A typology of stakeholder analysis methods for natural resources management. Journal of Environmental Management, 90, 1933-1949. https://doi.org/10.1016/ j.jenvman.2009.01.001

Rijal, M., \& Noer, S. (2013). Peran modal sosial dalam pelestarian hutan. Jurnal Kebijakan dan Administrasi Publik, 17(2), 20-36. https://doi.org/10.22146/jkap. 6852

Rokhani, Sumarti, T., Damanhuri, D. S., \& Wahyuni, E. S. (2016). Dilema kolektivitas petani kopi: Tinjauan sosiologi weberian (Kasus petani kopi di Nagori Sait Buttu Saribu, Kecamatan Pamatang Sidamanik Kabupaten Simalungun, Sumatera Utara). Sodality: Jurnal Sosial Pedesaan, 4(1), 1-10. https://doi.org/ 10.22500/sodality.v4i1.14400
Saputro, A. W. D. (2012). Modal sosial dan persepsi masyarakat dalam pembangunan hutan tanaman rakyat di Kabupaten Ogan Komering Ilir [thesis]. Bogor: IPB University.

Sribudiani, E., Somadona, S., Sulaeman, R., Syafrinal, S., Yusuf, S., Amin, Y., ..., \& Djarwanto, D. (2019). Sifat fisis kayu berkualitas rendah dari Riau setelah melalui proses pengawetan pohon dengan teknik bandage dan infus. Wahana Forestra: Jurnal Kehutanan, 14(2), 30-37. https://doi.org/10.31849/forestra.v14i2.3515

Suharjito, D. (2013). Reforma agraria di sektor kehutanan: Mewujudkan pengelolaan hutan lestari, keadilan sosial dan kemakmuran bangsa. In H. Kartodihardjo (Ed.), Kembali ke jalan lurus: Kritik penggunan ilmu dan praktek pengelolaan kehutanan indonesia (pp. 423-449). Yogyakarta: FORCI Development dan Tanah Air Beta.

Suharti, S., Darusman, D., Nugroho, B., \& Sundawati, L. (2016). Strengthening social capital for propelling collective action in mangrove management. Wetlands Ecology and Management, 24(6), 683-695. http://doi.org/ 10.1007/s11273-016-9496-9

Umar, H. (2005). Metode penelitian untuk skripsi dan tesis bisnis. Jakarta: PT Raja Grafindo Persada.

Yatimah, D. (2015). Strategi fasilitasi perubahan sosial. Jakarta : FIP UNJ.

Zeffane, R., Tipu, S. A., \& Ryan, J. (2011). Communication, commitment \& trust: Exploring the triad. International Journal of Business and Management, 6(6), 77-87. http://doi.org/10.5539/ijbm.v6n6p77

Zulfahmi, Nelawati, \& Rosmaina. (2015). Kepadatan dan pola penyebaran pasak bumi (Eurycoma longifolia Jack.) di zona Alaman Kuyang, hutan larangan adat Kenegarian Rumbio. Jurnal Agroteknologi, 6(1), 41-46. http://doi.org/10.24014/ja.v6i1.1375 